\title{
Upper Esophageal Sphincter
}

National Cancer Institute

\section{Source}

National Cancer Institute. Upper Esophageal Sphincter. NCI Thesaurus. Code C33836.

A valve that is composed of muscles in the upper portion of the esophagus. 